\title{
Kebijakan Pemerintah Indonesia melalui Sekuritisasi Migrasi Pengungsi Rohingya di Aceh tahun 2012-2015
}

\author{
Hardi Alunaza S.D \\ M. Kholit Juani \\ Universitas Tanjungpura
}

\begin{abstract}
This paper is attempted to describe Indonesian policy in dealing with Rohingya Refugees in Aceh in 2015. This paper took the specific interest on securitization of migration theory to analyze the issue. This paper sketches three important points regarding Indonesian policy to solve the Rohingya refugees problems in Aceh. First, Indonesian Government will make new policy by adjusting the existing legislation on refugees. Second, Indonesia will accommodate the displaced Rohingya people. Third, Indonesian Government will work together with international community to solve the problems of Rohingya refugees.
\end{abstract}

Keywords: Indonesian Policy, Rohingya Refugees, Securitization of Migration

Tulisan ini bermaksud untuk menjelaskan kebijakan Indonesia dalam menyelesaikan permasalahan pengungsi Rohingya di Aceh pada tahun 2015. Tulisan ini menggunakan teori sekuritisasi migrasi untuk menjelaskan isu terkait. Tulisan ini menguraikan tiga poin penting tentang kebijakan Indonesia untuk menyelesaikan permasalahan pengungsi Rohingya di Aceh. Pertama, Pemerintah Indonesia membuat kebijakan baru dengan menyesuaikan peraturan yang telah ada terkait permasalahan pengungsi. Kedua, Indonesia memberikan akomodasi berupa penampungan sementara bagi para pengungsi Rohingya. Ketiga, Pemerintah Indonesia bekerja sama dengan komunitas internasional dalam menyelesaikan permasalahan pengungsi Rohingya.

Kata-kata Kunci: Kebijakan Indonesia, Pengungsi Rohingya, Sekuritisasi Migrasi 


\section{Pendahuluan}

Indonesia merupakan sebuah negara maritim yang memiliki lebih dari 17.000 pulau yang membentang dari Sabang sampai Merauke. Posisi Indonesia secara geografis berada pada kawasan yang strategis. Indonesia terletak di antara dua benua yaitu benua Asia dan Australia, sekaligus berada di antara dua Samudera yaitu Samudera Hindia dan Pasifik sehingga menjadikan Indonesia sebagai jalur pelayaran yang digunakan oleh pengungsi untuk menuju negara tujuan. Indonesia bukan merupakan negara tujuan utama bagi pengungsi yang berasal dari Benua Asia. Namun dikarenakan posisinya yang strategis, Indonesia menjadi salah satu negara persinggahan bagi para pengungsi lintas batas negara, terutama yang berasal dari daratan Indo-Cina sebelum mereka melanjutkan perjalanannya ke negara tujuan (Andimas, 2010) .

Indonesia masih belum memiliki peraturan hukum tegas mengenai penanganan dan penetapan status pengungsi tanpa dokumen yang jelas. Selain itu, Indonesia juga belum meratifikasi Konvensi Wina tahun 1951 dan Protokolnya tahun 1967 yang membahas mengenai status pengungsi. Maka dari itu, Indonesia tidak mempunyai wewenang maupun kewajiban untuk melakukan suatu tindakan internasional terhadap para pengungsi lintas batas negara seperti pengungsi Rohingya yang masuk ke wilayah Indonesia, khususnya yang berada di Aceh.

Seperti yang telah tertuang dalam Undang-Undang Dasar 1945, bahwa 'Kemanusiaan yang adil dan beradab' merupakan salah satu dasar negara Indonesia untuk turut serta membantu penanganan pengungsi lintas batas negara. Indonesia memiliki kewajiban untuk membantu para pengungsi atas dasar kemanusiaan dan penghormatan terhadap peraturan internasional. Sebelum menangani kasus pengungsi Rohingya, Indonesia telah berhasil menangani kasus pengungsi lintas batas negara yaitu kasus pengungsi Vietnam yang terjadi pada tahun 1975 dan pengungsi Timor Leste tahun 1999.

Menurut Undang-Undang Dasar 1945 pasal 28 G Ayat 2 yang menyatakan bahwa, "Setiap orang berhak untuk bebas dari penyiksaan atau perlakuan yang merendahkan derajat martabat manusia dan berhak memperoleh suaka politik dari negara lain". Hal inilah yang menjadi dasar hukum Indonesia untuk melindungi para pengungsi lintas batas negara di Indonesia. Kata setiap orang dalam kalimat tersebut berarti tidak ada batasan setiap siapapun untuk mendapatkan perlindungan hukum dari Indonesia tanpa melihat status kewarganegaraannya (Anggrainy, 2014).

Sikap kemanusiaan ini dibuktikan dengan ikut berpartisipasinya Indonesia dalam menangani masalah pengungsi di wilayahnya. Pemerintah Indonesia juga dengan sukarela menampung dan menyiapkan tempat tinggal sementara bagi pengungsi Rohingya. Namun, para pengungsi 
yang berada di penampungan ini tidak dapat tinggal lama, pemerintah memberi batasan waktu bagi mereka untuk dapat tinggal di tempat detensi imigrasi. Setelah kemudian batas waktu yang telah ditentukan habis, Pemerintah Indonesia tidak akan lagi memberikan perlindungan terhadap para pengungsi.

Bantuan kemanusiaan yang diberikan Pemerintah Indonesia kepada pengungsi Rohingya di Aceh telah membangunkan mata dunia untuk ikut serta dalam membantu mengatasi masalah krisis kemanusiaan tersebut. Bantuan dana yang dimaksudkan untuk memenuhi kebutuhan sementara para pengungsi Rohingya di Aceh telah diterima oleh Pemerintah Indonesia dari Amerika, Qatar, PBB, dan beberapa negara lain. Namun, bantuan dana tersebut nampaknya tidak dapat memecahkan masalah dengan seketika. Masalah utama yang dihadapi para pengungsi ini ialah bagaimana mendapatkan status kewarganegaraan yang jelas serta hak asasi manusia sehingga mereka dapat hidup dengan layak (Admin, 2015).

Para pengungsi ini datang ke Indonesia melalui beberapa tahap mulai tahun 2012 sampai dengan 2015. Mereka datang dengan menggunakan perahu-perahu nelayan yang sangat sederhana dan dengan persediaan makanan yang terbatas. Banyak dari mereka yang gagal di tengah perjalanan akibat kelaparan maupun kapal yang tenggelam karena sudah tua dan kelebihan muatan (Nuswanto, 2013). Menurut Heri Aryanto, Direktur dari Pusat Informasi dan Advokasi Rohingya-Arakan (PIARA), ia mencatat bahwa tidak semua kedatangan pengungsi Rohingya ke Indonesia berawal dari Myanmar dan langsung menuju ke Indonesia. Pada kedatangannya di Indonesia, para pengungsi Rohingya ini terdampar di beberapa wilayah di Indonesia seperti Aceh, Medan, Kepulauan Riau, hingga Banyuwangi, Jawa Timur. Kondisi yang sangat memprihatinkan karena kelaparan membuat mereka dengan terpaksa menyerahkan diri ke pihak keamanan dan imigrasi Indonesia yang diharapkan dapat memberikan makan dan minum yang layak.

Kebanyakan pengungsi Rohingya di Indonesia ini berada di daerah Aceh, hal ini dikarenakan posisinya yang terletak paling dekat dengan Myanmar dibandingkan wilayah Indonesia lainnya. Tercatat pada bulan Juni 2015 terdapat sekitar 1.722 orang pengungsi, yang terdiri dari 1.239 jiwa laki-laki, 244 jiwa perempuan, dan 239 jiwa anak-anak. Para pengungsi tersebut terbagi dalam empat wilayah berbeda di Aceh yaitu Aceh Utara dengan jumlah pengungsi 560 jiwa, Kota Langsa dengan jumlah 682 jiwa, Aceh Temiang sejumlah 47 jiwa, dan di Aceh Timur sebanyak 433 jiwa (Waluyo, 2015).

Menurut pengakuan dari salah satu pengungsi Rohingya di Aceh pada Maret 2013 silam, mereka telah menempuh perjalanan laut yang berbahaya dari Myanmar selama berminggu-minggu dengan menggunakan 
kapal nelayan yang sudah tua. Kapal tersebut berisi lebih dari 120 orang warga etnis Rohingya dengan perbekalan yang sangat sedikit. Akibatnya, banyak dari mereka yang meninggal karena kelaparan dan sakit. Ketika mereka sedang melewati perairan Thailand, kapal mereka ditembaki dan mengakibatkan 10 korban meninggal. Merekadigiring ke sebuah pulau, mesin-mesin kapal dan persediaan makanan diambil kemudian mereka dibiarkan terapung di tengah laut sampai akhirnya mereka tiba di perairan Indonesia dan kapal mereka ditarik menepi oleh kapal nelayan lokal (Nuswanto, 2013).

Derasnya arus pengungsi Rohingya yang datang ke Indonesia, khususnya di wilayah Aceh bukan tidak mungkin akan menimbulkan ketidakstabilan di dalam tubuh Indonesia itu sendiri. Dengan semakin tidak terkontrolnya para pengungsi Rohingnya di Indonesia(khususnya di Aceh), serta dengan ketidakjelasan status mereka ini,jika tidak segera ditangani dengan baik maka lambat laun akan menimbulkan dampak atau permasalahanyang akan merugikan bangsa Indonesia baik dari segi sosial, ekonomi, politik, budaya, maupun keamanan.

Selain karena letak geografis Indonesia yang sangat strategis, lemahnya sistem keamanan dan pengawasan Pemerintah Indonesia (terutama di daerah perbatasan) juga menjadi salah satu faktor terbesar yang menjadikan para pengungsi maupun imigran untuk singgah di Indonesia. Kehadiran pengungsi Rohingya ini sendiri dapat membawa dampak buruk bagi bangsa Indonesia apabila berkaitan dengan demografi (kependudukan), maupun sosial ekonomi yang secara tidak langsung akan berimbas pada meningkatnya tingkat kriminalitas yang ada di Indonesia, khususnya wilayah Aceh.

Indonesia merupakan salah satu dari 17 negara pengamat dalam dewan International Organization for Migration (IOM) sejak tahun 1999 (IOM, 2014). Indonesia yang notabene bukan merupakan negara anggota IOM telah banyak melakukan kontribusi dalam penanganan migrasi Rohingya di Aceh. Salah satunya yaitu dengan membuat rumah hunian (detensi) maupun kamp-kamp sementara untuk menampung pengungsi. Selain itu, Indonesia juga mempunyai banyak relawan dari berbagai daerah yang bertugas membantu dan menyediakan bahan pokok bagi para pengungsi.

Indonesia yang sampai saat ini belum meratifikasi perjanjian mengenai pengungsi oleh IOM, belum dapat sepenuhnya memberikan bantuan maupun perlindungan yang layak bagi para pengungsi Rohingya. Namun, hal ini juga bukan merupakan suatu tindakan yang tepat untuk dilakukan. Mengapa? Dengan Indonesia meratifikasi perjanjian mengenai pengungsi tersebut, justru akan berdampak pada kenyamanan para pengungsi, yang dikhawatirkan akan membuat lebih banyak lagi pengungsi 
Rohingya untuk berbondong-bondong datang ke Indonesia (Manap, 2011). Meski bukan sebagai negara anggota IOM, Indonesia bersama negaranegara anggota ASEAN dan UNHCR lainnya telah berupaya untuk saling bekerja sama menyelesaikan permasalahan tersebut (Islam, 2015).

\section{Teori Sekuritisasi Migrasi}

Philippe Bourbeau dalam teorinya menyebutkan bahwa: "Migration Securitization theory is a theory that a portrait of the movement of a person who passed the boundary of a country and is an order system that will underlie the movement of any person. This theory seeks to combine a system of migration into a security framework or in other words how migration can be a part of the security" (Bourbeau, 2011). Sekuritisasi Migrasi menurut Phillipe Bourbeau adalah sebuah teori yang menggambarkan tentang pergerakan seseorang yang melewati tapal batas suatu negara dan merupakan suatu tatanan sistem yang mendasari akan pergerakan setiap orang tersebut. Teori ini berusaha untuk menggabungkan antara suatu sistem migrasi ke dalam sebuah kerangka kerja keamanan atau dengan kata lain menjelaskan bagaimana migrasi dapat menjadi bagian dari keamanan itu sendiri. Menurut Philippe Bourbeau, migrasi dapat tercipta secara aman jika suatu negara memiliki legal (hukum), kebijakan pemerintah, serta saliancy terhadap migrasi maka migrasi tidak akan menimbulkan problem keamanan. "in order to better understand the phenomenon of securitized migration are safe, $i$ use three indicator; legal, policy statement, and saliency." (Bourbeau, 2011).

Dari pengertian teori migrasi tersebut dapat kita lihat bahwa dinamika migrasi yang terjadi pada setiap negara selalu berkaitan dengan adanya pelanggaran-pelanggaran yang berasal dari sifat para imigran itu sendiri. Hal ini tidak menutup kemungkinan terjadinya ancaman atas adanya migrasi dalam suatu negara. Maka, pengamanan merupakan suatu hal yang penting guna mengendalikan arus migrasi supaya tidak terjadi halhal yang dapat mengganggu keamanan suatu negara. Selain itu, peran dari komunitas internasional juga penting untuk menghadapi permasalahan yang dapat timbul akibat dari migrasi dalam suatu negara (Kevin, 2015). Dalam teori ini dijelaskan bagaimana migrasi dalam suatu negara dapat dikelola dengan baik, sehingga terhindar dari ancaman dan pelanggaran yang datang dari para imigran (Firdaus, 2014).

Philippe Bourbeau membagi teori Sekuritisasi Migrasi ini ke dalam dua kategori, yang selanjutnya terbagi lagi menjadi tiga dan lima indikator penting. Kategori tersebut yaitu pertama, Institutional Category (kategori institusi). Pada kategori ini, Philippe menyatakan bahwa: "The constitution is a set of indicators that offer on the securitization of migration in pairs". Institusi merupakan sebuah rangkaian indikator yang menawarkan tentang sekuritisasi migrasi secara berpasangan. Hal ini dilakukan dengan cara 
memasangkan atau menghubungkan antara suatu hal dengan hal lainnya yang memiliki kesamaan satu sama lain pada suatu institusi pemerintahan. Misalnya dengan memasukkan indikator hukum, kebijakan pemerintah serta memasukkan indikator keamanan dan migrasi yang telah terhubung dengan kebijakan suatu negara.

Kategori institusi ini terbagi menjadi tiga indikator penting. Pertama, Legal Indicator (hukum). Hukum memiliki peran yang sangat penting dalam segala hal, termasuk dalam proses sekuritisasi migrasi. Setiap negara pasti memiliki peraturan hukum tersendiri yang terkait dengan migrasi, baik itu mengenai tujuan, prosedur seorang warga asing yang ingin masuk ke negara tersebut, serta tindakan yang akan dilakukan oleh suatu negara jika terjadi ancaman keamanan dari para imigran.

Terkait dengan dampak konflik Rohingya, yaitu kasus manusia perahu yang banyak berdatangan ke beberapa negara, termasuk Indonesia, ia justru dinilai belum memiliki standar hukum yang jelas mengenai sekuritisasi migrasi. Dalam menangani kasus pengungsi Rohingya di Aceh, Indonesia masih menggunakan peraturan hukum yang ada dengan cara menyesuaikan peraturan hukum yang berlaku dengan proses penanganan pengungsi sambil menunggu pembuatan peraturan baru mengenai pengungsi secara lebih menyeluruh. Sampai saat ini, Indonesia terus mengupayakan mengenai peraturan presiden yang nantinya akan membahas tentang migrasi secara menyeluruh, sekaligus untuk mengupayakan pencarian suaka. Indonesia bersama UNHCR, ASEAN, IOM, dan NGO lainnya sedang mengupayakan pencarian suaka maupun pemulangan kembali pengungsi dengan status kewarganegaraan yang jelas (Gabrillin, 2015).

Indikator kedua merupakan Policy Statement Indicator (kebijakan pemerintah). Sebuah proses migrasi sering kali berkaitan dengan keamanan suatu negara. Hal ini dikarenakan setiap aktivitas migrasi yang cenderung selalu menimbulkan permasalahan-permasalahan mengenai keamanan. Permasalahan ini pada akhirnya akan menjadi sebuah ancaman bagi negara. Permasalahan tersebut dapat berupa illegal migration hingga kasus terorisme transnasional yang akan mengancam stabilitas keamanan suatu negara.

Philippe berkata bahwa, "..in order to help smooth the securitization of migration by a country will require an element or institutions consern on security issues in migration" (Barbeau, 2011). Dapat diartikan bahwaa untukmembantu kelancaran sekuritisasi migrasi oleh suatu negara maka diperlukan sebuah elemen atau lembaga yang fokus terhadap permasalahan keamanan dalam migrasi.

Indonesia telah memiliki suatu institusi baru yang berada di jajaran Direktorat Jenderal Imigrasi yang disebut dengan Rudenim. 
Rudenim memiliki tugas untuk melaksanakan sebagian tugas pokok dari Kementerian Hukum dan Hak Asasi Manusia Republik Indonesia di bidang pendetensian orang asing. Indonesia mengambil keputusan untuk menampung para pengungsi Rohingya di Aceh atas dasar kemanusiaan. Hal ini sesuai dengan dasar negara Indonesia 'Kemanusiaan yang adil dan beradab'. Dalam penanganan pengungsi Rohingya di Aceh, Indonesia untuk sementara waktu menampung, melindungi, dan memberikan kebutuhan pokok para pengungsi sambil menunggu keputusan yang jelas mengenai kebijakan yang akan Pemerintah Indonesia ambil ke depannya.

Indikator ketiga dalam kategori instistusi adalah Saliency Indicator. Saliancy Indicator merupakan sebuah kekuatan yang menghubungkan antara migrasi dan keamanan. Dalam hal ini, saliancy dikaitkan dengan seberapa kuatnya hubungan antara migrasi dengan keamanan di dalam kebijakan suatu negara. Hal tersebut dapat kita lihat ketika permasalahan tentang migrasi sudah menjadi permasalahan utama dalam sebuah negara sehingga masalah ini dijadikan sebagai prioritas utama dalam sebuah kebijakan (Firdaus, 2014).

Dengan dijadikannya permasalahan migrasi sebagai prioritas utama yang harus diselesaikan oleh suatu negara, maka perlu adanya pemberitahuan dan kerja sama dengan suatu organisasi maupun negara lain untuk turut serta membantu mengatasi permasalahan tersebut. Hal ini dilakukan karena kasus migrasi ilegal yang berlebihan seperti ini dapat membahayakan stabilitas keamanan suatu negara.

Hubungan kedua hal tersebut membuat Indonesia dan beberapa negara ASEAN lainnya merasakan dampak dari konflik Rohingya. Banyaknya pengungsi konflik Rohingya yang menyebar ke beberapa negara menjadikan isu ini harus segera ditangani dengan serius. Maka dari itu, Indonesia sebagai salah satu negara penampung pengungsi Rohingya berusaha mengupayakan kejelasan atas status mereka dengan cara bekerja sama dengan UNHCR, ASEAN, IOM, dan beberapa organisasi NGO lainnya agar masalah ini dapat segera terselesaikan dengan baik.

Selanjutnya, kategori yang kedua adalah Security Practice Category (kategori praktik keamanan). Kategori ini menjelaskan mengenai praktik atau tindakan yang dilakukan terkait dengan keamanan migrasi. Pelaksanaan ini merupakan implementasi dari proses sekuritisasi migrasi. Praktik keamanan sangat penting karena pencapaian keamanan pada proses migrasi dalam suatu negara harus didukung dengan pelaksanaan kemanan, tidak hanya mengandalkan hukum dan kebijakan saja.

Philippe membagi kategori praktik keamanan menjadi dua indikator. Pertama yaitu pencegahan (Interdiction Indicator) yang bertujuan untuk menghentikan atau mengalihkan arus migrasi yang ada. Yang kedua, indikator penahanan (Detention) yang berguna ketika ada tindakan 
ancaman maupun pelanggaran yang dilakukan imigran. Apabila ada tindakan pelanggaran, kemudian akan dilakukan penahanan sesuai dengan hukum yang berlaku dan prosedur yang ada guna memberikan rasa jera terhadap para pelaku tindak kejahatan. Seperti yang terjadi pada salah satu relawan wanita Indonesia yang mengalami pelecehan seksual oleh salah satu pengungsi Rohingya di Aceh. Pelaku kejahatan tersebut selanjutnya diproses sesuai dengan prosedur dan hukum yang berlaku (Pribumi, 2015).

Tulisan ini merupakan penelitian deskriptif dengan pendekatan kualitatif. Penulis berusaha untuk memberikan gambaran atau mendeskripsikan keadaan objek serta permasalahan yang ada. Oleh karena itu, metode deskriptif ini diharapkan dapat digunakan untuk mencapai tujuan penelitian, yaitu menggambarkan secara jelas fakta dan karakteristik objek yang diteliti secara tepat.

\section{Berbagai Upaya Indonesia dalam Menangani Pengungsi Rohingya di Aceh}

Kasus pengungsi asal Rohingya yang masuk ke Indonesia merupakan suatu bentuk masalah illegal migration yang harus segera ditangani dengan serius. Masalah pengungsi Rohingya ini merupakan suatu masalah yang kompleks. Maka daripada itu, penanganan masalah tersebut harus menggunakan cara-cara yang saling berkaitan, mulai dari tatanan domestik/ nasional sampai ke tingkat kerja sama internasional.

Kurangnya perhatian serta penanganan mengenai masalah Rohingya membuat kondisi para pengungsi Rohingya semakin memprihatinkan. Hal ini disebabkan karena faktor internal dan faktor eksternal. Faktor internal yang dimaksud adalah permasalahan yang berasal dari pemerintah Indonesia sendiri, seperti kurangnya regulasi hukum yang lengkap mengenai pengungsi. Sedangkan faktor eksternalnya yaitu belum diratifikasinya Konvensi Wina 1951 oleh Pemerintah Indonesia. Penanganannya pun bisa dilaksanakan melalui dua faktor tersebut, yaitu dengan cara menghubungkannya ke dalam konvensi tahun 1951 tentang pengungsi. Indonesia juga harus ikut berperan aktif dalam penyelesaian masalah ini agar arus pengungsi, terutama yang telah berada di Aceh segera terselesaikan. Semua pihak yang bersangkutan juga harus turut serta dalam penyelesaian masalah tersebut sampai ke akarnya karena selama masalah yang ada di Arakan belum selesai, maka arus pengungsi akan terus terjadi sepanjang waktu (Aryanto, 2014).

Beberapa tahun terakhir, terdapat ribuan orang pengungsi asal Rohingya dan Bangladesh yang masuk ke Indonesia. Para pengungsi Rohingya masuk ke Indonesia dengan keadaan yang sangat memprihatinkan. Mereka terkatung-katung di tengah laut dengan kondisi kelaparan dan berdesak-desakan menggunakan kapal nelayan yang sudah 
tak layak pakai. Para pengungsi akhirnya diselamatkan dan kapal mereka ditarik ke pantai oleh nelayan setempat atas dasar kemanusiaan, kemudian ditampung sementara di beberapa wilayah di Aceh.

\section{Menyesuaikan Peraturan yang Ada Tentang Pengungsi}

Indonesia belum memiliki regulasi hukum yang jelas dalam menangani masalah pengungsi lintas batas negara. Di sisi lain, sampai saat ini Indonesia juga bukan merupakan negara yang telah meratifikasi Konvensi Wina 1951 dan protokolnya tahun 1967 tentang pengungsi. Maka dari itu, Pemerintah Indonesia tidak mempunyai kewajiban dan kewenangan dalam melakukan tindakan internasional mengenai pengungsi ini secara lebih lanjut. Indonesia hanya dapat menampung dan memberikan fasilitas yang dibutuhkan oleh pengungsi Rohingya atas dasar kemanusiaan sambil menunggu tindak lanjut dan proses dari pihak UNHCR (Susetyo, 2013).

Selanjutnya, Pemerintah Indonesia telah berupaya membuat kebijakan serta peraturan hukum mengenai pencari suaka dan pengungsi yang ada di Indonesia. Indonesia membutuhkan suatu kerangka hukum yang membahas mengenai pengungsi asing secara jelas. Kerangka hukum tersebut bisa berasal dari kerangka hukum nasional dan sebagai pendukungnya dibutuhkan pula kerangka hukum internasional. Kerangka hukum internasional yang dimaksud bisa berasal dari Konvensi Wina 1951. Dengan demikian, maka Indonesia diharapkan akan dapat menangani para pengungsi lintas batas negara dengan lebih baik.

Kepedulian Indonesia terhadap pengungsi Rohingya juga ditunjukkan dengan berbagai upaya nyata yang sudah ia lakukan. Salah satunya adalah dengan kerjasama antara Pemerintah Indonesia dengan organisasi internasional untuk memberikan bantuan terkait krisis pengungsi Rohingya yang ada di Aceh. Hal ini menunjukkan bahwa Pemerintah Indonesia dengan tegas telah menerapkan nilai-nilai konstitusi negara sesuai dengan Undang-Undang Dasar Negara Republik Indonesia Tahun 1945. Serta menunjukkan bahwa Indonesia memiliki suatu komitmen yang kuat untuk menjaga stabilitas keamanan negara yang berdasarkan atas perdamaian dunia.

Indonesia sebagai salah satu negara yang menampung pengungsi Rohingya memiliki serangkaian aturan hukum yang mengatur tentang pengungsi. Namun, aturan hukum yang ada di Indonesia belum sepenuhnya dapat digunakan untuk menangani permasalahan-permasalahan pengungsi tersebut. Salah satu peraturan mengenai pengungsi yang dimiliki Indonesia tertuang dalam Undang-Undang No. 39 Tahun 1999 tentang Hak Asasi Manusia, undang-undang tersebut berbunyi: "Setiap orang berhak mencari suaka untuk memperoleh perlindungan politik dari negara lain". Namun, dalam Undang-Undang Nomor 37 Tahun 1999 tentang Hubungan 
Luar Negeri menyebutkan bahwa untuk menangani kasus pengungsi harus melalui Keputusan Presiden (Keppres). Ini dilakukan untuk mengklasifikasi kasus pengungsi yang ada di Indonesia. Setiap kasus pengungsian mempunyai faktor penyebab yang berbeda-beda, sehingga dibutuhkan pranata khusus untuk menangani setiap kasus pengungsi yang terjadi pada saat itu. Dalam menangani masuknya pengungsi, Indonesia belum memiliki standar hukum yang jelas. Indonesia masih menggunakan keputusan presiden dengan ketentuan yaitu para pengungsi tersebut harus memiliki dokumen resmi yang lengkap (Muafi, 2015).

Indonesia sebenarnya dapat melakukan tindakan-tindakan yang perlu dilakukan sesuai dengan aturan hukum internasional selama tindakan tersebut tidak bertentangan dengan aturan hukum positif Indonesia. Untuk menangani para pengungsi yang masuk di Indonesia, pemerintah selama ini berpedoman pada peraturan hukum yang dikeluarkan oleh Direktorat Jenderal Imigrasi Kementerian Hukum dan HAM yang membahas tentang pengungsi dan asylum seeker. Ketentuan-ketentuan yang telah dikeluarkan oleh Dirjen Imigrasi Kementerian Hukum dan HAM tersebut sebagian besar menyebutkan bahwa Pemerintah Indonesia tidak boleh mendeportasi para pengungsi atau pencari suaka ke negara asal mereka.

Ketentuan untuk tidak mendeportasi tersebut telah tercantum dalam Undang-Undang Nomor 5 Tahun 1998 tentang Pengesahan Konvensi Menentang Penyiksaan atau Penghukuman yang Kejam, Tidak Manusiawi atau Merendahkan Martabat Manusia (CAT), Pasal 3 Undang-Undang ini menyatakanbahwa, "Tidakbolehadanegara yang menolak, mengembalikan, atau mengekstradisi seseorang ke negara yang mana terdapat keyakinan atau alasan yang kuat bahwa dia akan berbahaya karena menjadi sasaran penyiksaan". Setelah Pemerintah Indonesia menampung para pengungsi dan pencari suaka, selanjutnya mereka didata dan kemudian data tersebut diserahkan kepada UNHCR untuk diproses lebih lanjut.

Tindakan yang diambil oleh Pemerintah Indonesia untuk menangani permasalahan pengungsi Rohingya di Aceh dapat dilakukan secara internal dan eksternal. Cara internal dilakukan dengan memperbaiki kebijakan maupun peraturan hukum Indonesia mengenai penyelesaian permasalahan pengungsi di negaranya. Sehubungan dengan hal tersebut, Indonesia telah memperbarui peraturan pemerintah tentang keimigrasian, tepatnya tertulis pada Pasal 206, 221, dan 223 Peraturan Pemerintah Nomor 31 Tahun 2013. Pasal-pasal tersebut mengandung ketentuan-ketentuan yang ada pada peraturan presiden, serta mengatur tentang pendetensian pengungsi (imigran ilegal) hingga jangka waktu 10 tahun. Peraturan Presiden tersebut mengatur bahwa setelah jangka waktu 10 tahun, pendetensian pengungsi dapat dikeluarkan dengan kewajiban melapor selama enam bulan sekali serta kewajiban melapor ke kantor imigrasi apabila ada perubahan status dan pekerjaan mereka. 


\section{Membuat Lembaga Baru}

Masuknya pengungsi asing dari negara lain, khususnya Myanmar di wilayah Indonesia cenderung berpotensi meningkatkan berbagai permasalahan keimigrasian, sehingga diperlukan adanya upaya untuk menindaklanjuti imigran yang berdasar pada ketentuan dari lembaga keimigrasian. Guna mempermudah dan mengefisienkan pelaksanaan tugas di bidang penindaklanjutan keimigrasian, maka diperlukan sarana dan prasarana pendukung yang fokus terhadap permasalahan migrasi antara lain yaitu Rumah Detensi Imigrasi.

Seperti yang tertuang dalam Peraturan Menteri Hukum dan HAM RI No. M05.IL.02.01 Tahun 2006 Pasal 1 Ayat (1), Rumah Detensi Imigrasi (Rudenim) merupakan tempat penampungan sementara bagi orang asing yang melanggar peraturan perundang-undangan atau bagi yang dikenakan tindakan keimigrasian dan menunggu untuk menjalani proses pemulangan ke negaranya. Rudenim merupakan salah satu institusi baru di jajaran Direktorat Jenderal Imigrasi yang mempunyai tugas untuk menjalankan sebagian dari tugas pokok Kementerian Hukum dan HAM RI dalam bidang pendetensian orang asing.

Dalam pelaksanaannya, Rudenim memiliki fungsi sebagai berikut: melaksanakan tugas penindakan serta penampungan untuk para pengungsi lintas batas negara; melaksanakan tugas pengisolasian; serta membantu pelaksanaan tugas pemulangan dan pengusiran atau deportasi. Penempatan dan penampungan orang asing bertujuan untuk mendukung penegakan hukum di bidang keimigrasian, khususnya bagi para imigran yang melanggar peraturan perundang-undangan yang berlaku. Tindakan keimigrasian pada Rumah Detensi Imigrasi tersebut dilaksanakan atas UU Nomor 9 Tahun 1992 tentang Keimigrasian, Peraturan Pemerintah No. 30 Tahun 1994 tentang Tata Cara Pencegahan dan Penangkalan, dan Peraturan Pemerintah No. 31 Tahun 1994 tentang Pengawasan Orang Asing dan Tindakan Keimigrasian.

Indonesia bukan merupakan negara peratifikasi Konvensi Wina tahun 1951 dan Protokolnya tahun 1967. Namun dalam praktiknya, Indonesia telah melakukan beberapa hal yang ada dalam Konvensi tersebut yaitu berupa penampungan pengungsi Rohingya di Indonesia. Indonesia merupakan salah satu negara yang memberikan respon positif terhadap pengungsi Rohingya. Hal ini dapat dilihat dari diberikan izin dan ditampungnya para pengungsi Rohingya asal Myanmar ini di Rudenim yang telah disediakan di beberapa wilayah Aceh. Namun, keberadaan para pengungsi Rohingya di rumah detensi imigrasi ini juga memiliki batas waktu tersendiri. Indonesia sebagai negara yang memiliki dasar negara 'Kemanusiaan yang adil dan beradab', hanya dapat membantu para korban dengan cara menampung mereka hingga mampu melanjutkan perjalanan. 
Tempat penampungan bagi pengungsi etnis Rohingya ini berada pada sejumlah wilayah di Aceh yaitu Kota Langsa, Aceh Temiang, Kabupaten Aceh Timur dan Kabupaten Aceh Utara. Menurut laporan dari Kepala Dinas Sosial Provinsi Aceh, Al Hudri, terdapat lebih dari 1.700 orang yang tersebar di beberapa wilayah tersebut. Dari laporan tadi juga diperoleh data bahwa jumlah pengungsi yang meninggal akibat sakit sebanyak 2 orang dan sejumlah 13 orang yang terkena penyakit TBC sehingga akhirnya dideportasi ke medan.

Mayoritas pengungsi Rohingya tersebut adalah laki-laki dengan jumlah sebanyak 1.239 jiwa. Lainnya yaitu sebanyak 244 jiwa perempuan dan 239 anak-anak. Mereka tersebar ke dalam empat wilayah di Provinsi Aceh yaitu Aceh Utara sebanyak 560 orang pengungsi, Kota Langsa sejumlah 682 orang, Aceh Temiang sejumlah 47 orang, dan di Aceh Timur sebesar 433 orang pengungsi. Data ini diperoleh pada bulan Juni 2015 (Waluyo, 2015).

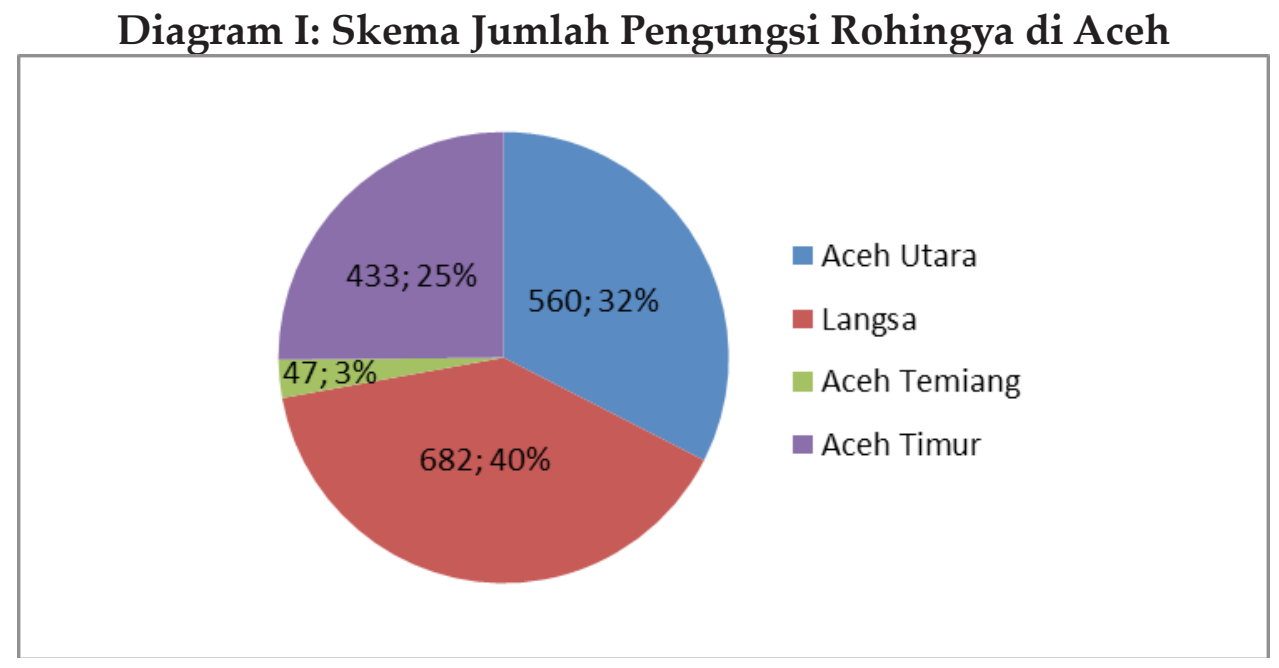

Indonesia merupakan salah satu negara yang memberikan tempat penampungan beserta fasilitas yang cukup baik dibandingkan dengan negara lainnya, dalam konteks penanganannya terhadap para pengungsi Rohingya Hal ini dibuktikan dengan lengkapnya sarana dan prasarana penunjang kebutuhan sehari-hari bagi pengungsi. Seperti dengan tersedianya tempat ibadah, sekolah, dan klinik/rumah sakit hingga aula tempat para pengungsi dapat saling bersosialisasi dengan pengungsi lain maupun warga sekitar.

Para pengungsi yang telah berkeluarga juga mendapatkan kamar sendiri guna memenuhi kebutuhan seksualitasnya. Secara umum, mereka mendapatkan jatah makan tiga kali sehari dengan menu yang bergantiganti untuk menghindari kebosanan. Setiap hari, makanan dapat diperoleh 
pada jam-jam tertentu. Akibat dari Indonesia yang sebenarnya tidak memiliki tanggung jawab penuh terhadap para pengungsi Rohingya ini, maka sumber dana yang dikeluarkan untuk memenuhi kebutuhan para pengungsi berasal dari IOM dan sumbangan para relawan beberapa pihak. Peran UNHCR ialah memproses para pengungsi secara lebih lanjut, menentukan apakah pengungsi tersebut berhak memperoleh status sebagai pengungsi internasional dan pencari suaka atau tidak.

\section{Kerja Sama dengan Komunitas Internasional}

Proses penyelesaian krisis pengungsi (khususnya di kawasan Asia Tenggara) yang sedang terjadi pada pengungsi Rohingya harus segera diselesaikan dengan melibatkan semua pihak. Tidak hanya dengan melibatkan negara-negara ASEAN, namun juga harus bekerja sama dengan komunitas-komunitas internasional lainnya yang secara fokus juga membahas permasalahan yang sama, yaitu pengungsi (refugee).

Masalah pengungsi lintas batas negara dapat sewaktu-waktu berimbas pada stabilitas keamanan suatu negara. Hal ini telah terjadi pada kasus pengungsi yang berasal dari etnis Rohingya. Semakin meningkatnya arus pengungsi Rohingya dapat mengganggu keamanan negara, sehingga harus ditempatkan atau diprioritaskan oleh negara dan organisasi internasional terkait agar dapat segera diselesaikan bersama. Maka, saat ini pemerintah Indonesia telah bekerja sama dengan aktor-aktor terkait untuk segera mencarikan solusi terhadap pengungsi Rohingya agar tidak bertambah parah ke depannya.

Dalam kasus ini, Indonesia yang merupakan salah satu negara penampung pengungsi asal Rohingya bekerja sama dengan ASEAN, PBB, dan IOM dalam penanganan masalah tersebut. Posisi Indonesia dan Myanmar sebagai anggota ASEAN telah mendorong ia dan aktor-aktor terkait untuk segera membahas permasalahan ini secara bersama-sama dalam forum-forum internasional (ASEAN).

Indonesia yang merupakan salah satu negara anggota ASEAN mempunyai posisi yang jelas untuk menjaga stabilitas keamanan nasional dari berbagai ancaman keamanan kawasan. Dalam penanganannya, sehubungan dengan permasalahan pengungsi Rohingya, terdapat dilema yang menghambat negara-negara ASEAN untuk saling bekerja sama mengakhiri masalah tersebut. Hambatan itu berasal dari salah satu kesepakatan yang menjadi dasar prinsip negara anggota ASEAN. Kesepakatan yang dimaksud telah menjadi dasar dari organisasi tersebut dan tercatat dalam Piagam ASEAN. Prinsip dasar yang diterapkan oleh ASEAN tersebut adalah prinsip non-intervensionism.

Di lain pihak, sikap yang ditunjukkan oleh PBB sudah semakin proaktif. PBB telah mengirimkan utusan-utusannya ke wilayah Arakan 
di Myanmar untuk segera mendesak Pemerintah Myanmar agar segera menyelesaikan permasalahan yang ada. Sayangnya, sampai saat ini PBB masih belum memberikan peringatan dan sanksi yang tegas terhadap Pemerintah Myanmar mengenai permasalahan Rohingya. PBB seharusnya telah mengirimkan misi keamanan serta pemeliharaan perdamaian ke Myanmar, namun hal itu belum terjadi hingga sekarang (Susetyo, 2013).

Pemerintah Indonesia telah bekerja sama dengan UNHCR dan IOM guna membentuk suatu Tim Verifikasi Gabungan (TVG/Tim) untuk mempermudah penetapan status pengungsi Rohingya. UNHCR merupakan anak dari organisasi internasional PBB secara khusus juga menangani tentang permasalahan pengungsi (refugee). UNHCR berkolaborasi dengan IOM untuk bekerja sama membahas permasalahan pengungsi yang ada di seluruh dunia.

Presiden Republik Indonesia melakukan suatu pertemuan khusus dengan Perdana Menteri Myanmar pada 6 Maret 2009 di Jakarta. Dalam pertemuan tersebut dihasilkan upaya-upaya penanganan kasus pengungsi yang ada di Indonesia. Penanganan tersebut dapat melalui tataran nasional maupun kerja sama bilateral dan regional. Indonesia juga mendesak agar pemerintah Myanmar segera mengupayakan penyelesaian konflik yang ada di negara mereka tersebut.

Guna mengaplikasikan salah satu hasil pertemuan Presiden RI dengan Perdana Menteri Myanmar tersebut, maka Indonesia yang diwakili oleh Kementerian Luar Negeri telah mengirimkan salah satu utusannya ke Myanmar pada tanggal 31 Maret sampai 4 April 2009. Utusan tersebut dimaksudkan untuk melihat upaya Myanmar dalam menangani masalah yang ada di negaranya tersebut, serta guna mengkonsultasikan lebih jauh mengenai penanganan masalah yang praktis dan komprehensif. Pemerintah Myanmar telah menyampaikan bahwa negaranya dapat menerima kembali para manusia perahu dan akan mengakui status kewarganegaraannya, asalkan mereka dapat membuktikan diri sebagai bagian dari masyarakat Myanmar.

Dalam hal ini, negara-negara anggota ASEAN mendukung dan bersikap serius dalam menyelesaikan permasalahan pengungsi Rohingya. Kemudian, mereka bersepakat untuk membawa dan membahas masalah ini dalam KTT ASEAN ke-14 yang diadakan di Thailand pada tanggal 28 Februari sampai 1 Maret 2009. Dari hasil pembahasan pada forum tersebut, disepakati bahwa permasalahan pengungsi Rohingya ditangani melalui mekanisme 'Bali Process'. Penanganan tersebut membutuhkan konteks yang lebih luas serta melibatkan negara-negara terkait, yaitu negara asal, transit, dan tujuan para pengungsi (Kadarudin, 2015). 


\section{Kesimpulan}

Dalam menangani masalah pengungsi lintas batas negara, Indonesia belum memiliki regulasi hukum yang jelas. Indonesia juga belum meratifikasi Konvensi Wina 1951 dan Protokolnya Tahun 1967 tentang Pengungsi. Hal ini mengakibatkan Pemerintah Indonesia tidak mempunyai kewajiban dan kewenangan dalam melakukan tindakan internasional mengenai pengungsi Rohingya yang masuk ke Aceh secara lebih jauh. Indonesia hanya dapat menampung sementara serta memberikan fasilitas dan kebutuhan-kebutuhan pokok yang diperlukan pengungsi selama berada di Aceh, kemudian selebihnya akan diproses dan ditindaklanjuti oleh pihak UNHCR.

Sebagai salah satu negara yang menampung pengungsi Rohingya, Indonesia memiliki serangkaian aturan hukum yang mengatur tentang pengungsi. Namun, aturan hukum yang ada di Indonesia belum sepenuhnya dapat digunakan untuk menangani permasalahan-permasalahan pengungsi yang masuk. Sebagai negara yang memiliki dasar negara 'Kemanusiaan yang adil dan beradab', Indonesia hanya membantu para korban atas dasar kemanusiaan dengan cara menampung mereka sampai beban pengungsi menjadi lebih ringan. Indonesia memberikan batasan waktu tinggal kepada pengungsi asal Rohingya yang ada di Rudenim seluruh Indonesia selama 10 tahun. Setelah masa penampungan yang ditetapkan berakhir, Indonesia sudah tidak bertanggung jawab dan tidak akan memberikan perlindungan lagi terhadap para pengungsi lintas batas negara tersebut.

Penyelesaian kasus ini tidak hanya melibatkan negara-negara ASEAN, namun Indonesia juga harus bekerja sama dengan komunitaskomunitas internasional lain yang secara fokus juga membahas mengenai permasalahan yang sama. Indonesia yang merupakan salah satu negara penampung pengungsi asal Rohingya bekerja sama dengan ASEAN, PBB, dan IOM untuk bekerja bersama dalam penanganan permasalahan tersebut. Posisi Indonesia dan Myanmar sebagai anggota ASEAN telah mendorong Indonesia dan aktor-aktor lain yang terlibat untuk segera membahas masalah ini secara bersama-sama dalam forum-forum internasional (ASEAN).

\section{Daftar Pustaka}

Amrullah, M. (2014) Peran IOM dalam menangani pengungsi Afghanistan di Indonesia. Jakarta.

Asfwr, A.M. (2015). Pengungsi Bisa Menjadi Masalah Baru BagiSekali Buka Akses, Suku Rohingya Eksodus ke Indonesia [online]. Solopos. Tersedia di: <http:// www.soloposcm/2015/05/16/pengungsi-rohingya-sekali-buka-akses-sukurohingya-eksodus-ke-indonesia-604710.> [diakses 16 November 2015].

Bourbeau, P. (2011.) The Securitization of Migration: A Study of Movement and Order. New York: Routledge.

Cardoso, J.L.P. (2011) Pilihan Pengungsi Timor-Timur Menjadi Warga Negara Ind 
onesia. Yogyakarta: Universitas Pembangunan Nasional.

Fandi,A. (1999.) Undang-Undang Dasar 1945 Amandemen Pertama - Ke Empat (1999-2002). Jakarta: Setia Kawan.

Fitria. (2013.) Penanganan Pencari Suaka dan Pengungsi di Indonesia: Dilema Peraturan Setengah Hati. Jakarta: PAHAM dan PIARA.

Gabrillin, A. (2005) Belum Ada Rencana Pemulangan, Pengungsi Rohingya Diizinkan Tinggal di Aceh [online]. Kompas. Tersedia di: <http://nasional. kompas.com/read/2015/05/24/1837156/Belum.Ada.Rencana.Pemulangan. Pengungsi.Rohingya.Diizinkan.Berada.di.Aceh.> [diakses 27 September 2015)].

Hardoko, E. (ed.)B. (2015). Mengapa Etnis Rohingya Meningalkan Myanmar [online] Kompas. Tersedia di: <http://internasional.kompas.com/ $\mathrm{read} / 2015 / 05 / 22 / 19023781 /$ Mengapa.Etnis.Rohingya.Meninggalkan. Myanmar.> [diakses 16 November 2015)].

Haryomataram. (2005.) Pengantar Hukum Humaniter. Jakarta: Rajawali Pers.

Heruiani. (2010.) Kewenangan UNHCR dalam Penanganan Masalah Pengungsi Asing Riau: Pekanbaru.

Messakh, T.A. (2003.) Kebijakan Pemulangan Kembali Pengungsi di Perbatasan Indonesia-Timor Leste. Semarang: Universitas Diponegoro.

Perwita, B. dan Yani, M. (2005) Pengantar Hubungan Internasional. Bandung: Remaja Rosda Karya.

Proudfoot, M. (1957.) European Refugee: A Study in Forced Migration Movement. London: Faber \& Faber Ltd.

Rastika, Icha. (2015.) Pemerintah Antisipasi Adanya Konflik Sosial Akibat Pengungsi Rohingya [online]. Kompas. Tersedia di: <http://nasional. kompas.com/read/2015/05/21/21503561/Pemerintah.Anitisipasi.Adanya. Konflik.Sosial.akibat.Pengungsi.Rohingya.> [diakses 19 November 2015)].

Republik Indonesia (2000). Undang-Undang Republik Indonesia No. 26 Tahun 2000 tentang Pengadilan Hak Asasi Manusia. Jakarta.

Republik Indonesia (1945). Undang-Undang Dasar Negara Kesatuan Republik Indonesia Tahun 1945. Jakarta.

Republik Indonesia (1998). Tap MPR Nomor XVII/MPR 1998 tentang Deklarasi Unversal Hak Asasi Manusia (DUHAM). Jakarta.

Sarnia, P. (2015.) Ini Alasan Kaum Rohingya Kabur dari Myanmar [online]. Okezone. Teredia di<http://news.okezone.com/read/2015/05/23/18/1154199/ ini-alasan-kaum-rohingya-kabur-dari-myanmar.> [diakses 16 November 2015)].

UNHR (2005). Pengenalan Tentang Perlindungan Internasional, Melindungi Orang-Orang yang Menjadi Perhatian UNHCR. Switzerland: Komisariat Ting gi PBB untuk Urusan Pengungsi.

United Nations (1951). Convention Relating to the Status of Refugees 1951. New York: UNGA.

United Nations (1967). Protocol Relating to the Status of Refugees 1967. New York: UNGA.

United Nations (1969). Vienna Convention on the Law of Treaties. New York: UN G eneral Secretariat. 
Verri, P. (1992). Dictionary of The International Law and Armed Conflict, Interna tional Committee of The Red Cross. Geneva.

Wauyo, A. (2015). Pemerintah Indonesia Siapkan Lokasi Baru Pengungsi Rohingya dan Bangladesh [online]. VOA Indonesia. Tersedia di: <http://www. voaindonesia.com/content/pemerintah-indonesia-siapkan-lokasi-barupengungsi-rohingya-dan-bangladesh/2808703.html.> [diakses 14 Oktober 2015)]. 